\title{
Smaragdicoccus niigatensis gen. nov., sp. nov., a novel member of the suborder Corynebacterineae
}

\author{
Correspondence \\ Hiroaki Kasai \\ hiroaki.kasai@mbio.jp
}

\author{
Kyoko Adachi, ${ }^{1}$ Atsuko Katsuta, ${ }^{1}$ Satoru Matsuda, ${ }^{1}$ Xue Peng, ${ }^{1}$ \\ Norihiko Misawa, ${ }^{1}$ Yoshikazu Shizuri, ${ }^{1}$ Reiner M. Kroppenstedt, ${ }^{2}$ \\ Akira Yokota ${ }^{3}$ and Hiroaki Kasai ${ }^{1}$
${ }^{1}$ Marine Biotechnology Institute, 3-75-1 Heita, Kamaishi, Iwate 026-0001, Japan
${ }^{2} \mathrm{DSMZ}$ - Deutsche Sammlung von Mikroorganismen und Zellkultren GmbH, Inhoffenstrasse 7b, D-38124 Braunschweig, Germany
${ }^{3}$ Institute of Molecular and Cellular Biosciences, University of Tokyo, 1-1-1 Yayoi, Bunkyo-ku, Tokyo 113-0032, Japan

Strain Hou_blue ${ }^{\mathrm{T}}$ was isolated from an enrichment culture containing petroleum-contaminated soil, obtained from the ground around a spurt of petroleum at Nishiyama-cho in Niigata, Japan, by using hexadecane as the sole carbon source. On W-medium (Peng et al., 2003) malachite greenlike, round colonies of $1-3 \mathrm{~mm}$ diameter were obtained after incubation for 7 days in a hexadecane-saturated atmosphere at $25^{\circ} \mathrm{C}$. Subcultivation was done on $1 / 10$ trypticase soy agar (TSA; Difco) at $30^{\circ} \mathrm{C}$ for 7 days. On this medium, strain Hou_blue ${ }^{\mathrm{T}}$ was able to grow at $4-37^{\circ} \mathrm{C}$, but not at $45^{\circ} \mathrm{C}$. Growth at $30^{\circ} \mathrm{C}$ was also observed on

\footnotetext{
The GenBank/EMBL/DDBJ accession numbers for the 16S rRNA and gyrB gene sequences of strain $\mathrm{Hou}_{\text {blue }}{ }^{\top}$ are AB243007 and AB243008, respectively.

A scanning electron micrograph of cells of strain Hou blue ${ }^{\top}$, a phylogenetic tree based on gyrB gene sequences and structures of the novel quinones present in strain $\mathrm{Hou}_{-}$blue $^{\top}$ are available as supplementary figures in IJSEM Online.
}

International Streptomyces Project (ISP) medium 2 (Daigo), medium 6 and TSA.

Gram-staining was performed as described by Gerhardt et al. (1994). Cell morphology was observed under a Nikon phase-contrast microscope at $\times 1000$, with cells grown for 14 days at $30^{\circ} \mathrm{C}$ on $1 / 10$ TSA. The size of the cells was determined by using a scanning electron microscope with specimens that were fixed with $2.5 \%$ glutaraldehyde in $0.1 \mathrm{M}$ cacodylate buffer containing several drops of $4 \%$ osmium tetroxide for $1 \mathrm{~h}$ at room temperature. Suspensions were transferred to the surface of a polylysine-coated glass plate, and dehydrated in ethanol and t-butyl alcohol at room temperature. Preparations were sputter-coated with $\mathrm{Pt} / \mathrm{Pd}$ on aluminium mounts and observed with a Hitachi S2500 scanning electron microscope (see Supplementary Fig. S1 in IJSEM Online). The $16 \mathrm{~S}$ rRNA and gyrB genes were analysed as described by Katsuta et al. (2005). Sequences were aligned by using CLUSTAL_X (Thompson et al., 1997) based on aligned sequences supplied by RDP-II release 9 (Cole et al., 
2005). A neighbour-joining phylogenetic tree based on genetic distances calculated using the Kimura two-parameter model was constructed with MEGA version 3.1 (Kumar et al., 2004). PHYML (version 2.4.4; Guindon \& Gascuel, 2003) was used to construct a maximum-likelihood tree. The phylogenetic relationship based on the GTR substitution model was analysed, and a tree was built up from the neighbour-joining tree as the starter tree. The robustness of the topology was evaluated by using the maximumlikelihood method with bootstrap analysis based on 100 replications (Fig. 1). The $16 \mathrm{~S}$ rRNA gene sequence of strain Hou_blue $^{\mathrm{T}}$ was a continuous stretch of $1478 \mathrm{bp}$. Sequence similarity calculations after a BLAST search against GenBank indicated that the closest relatives of strain Hou_blue ${ }^{\mathrm{T}}$ were Nocardia africana (95.0\%), Nocardia araoensis (94.5\%),
Nocardia arthritidis (94.8\%), Nocardia beijingensis (94.7\%), Nocardia elegans (94.9\%), Nocardia takedensis (94.5\%) and Nocardia paucivorans $(94.5 \%)$. Twelve of 16 signature nucleotides of the 16S rRNA gene in Nocardiaceae (Stackebrandt et al., 1997) were identified in the $16 \mathrm{~S}$ rRNA gene sequence of strain Hou_blue ${ }^{\mathrm{T}}$. The gyrB genebased phylogenetic tree is available as Supplementary Fig. S2 in IJSEM Online.

For analysis of cell-wall amino acids and sugars, cell walls were prepared from approximately $100 \mathrm{mg}$ (dry weight) bacterial cells, as described by Schleifer \& Kandler (1972). The amino acids in an acid hydrolysate of the cell walls were identified by using two-dimensional descending chromatography on cellulose TLC plates (Tokyo Kasei), following the

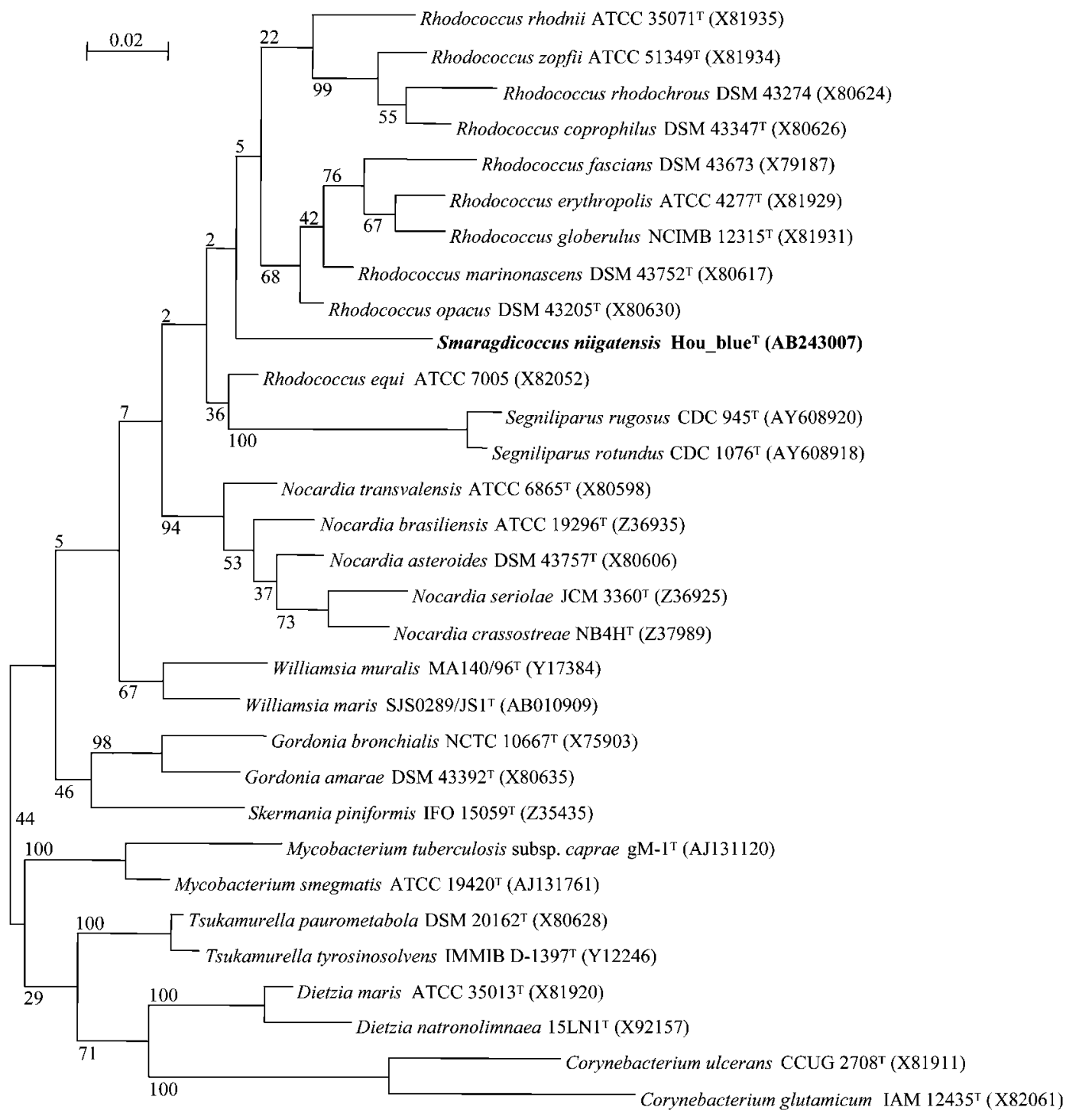

Fig. 1. Maximum-likelihood tree based on $16 \mathrm{~S}$ rRNA gene sequences. The sequence of Corynebacterium glutamicum was used to root the tree. Numbers at branch points are bootstrap percentages based on 100 replications. Bar, 0.02 substitutions per nucleotide position. 
method of Harper \& Davis (1979), and by HPLC as their phenylthiocarbamoyl derivatives, with LC-10AD HPLC apparatus (Shimadzu) equipped with a Wakopak WSPTC column (Wako Pure Chemical Industries, 1989). Whole-cell sugars were analysed using the method of Becker et al. (1964). The hydrolysate of whole cells of strain Hou_blue ${ }^{T}$ contained the sugars arabinose, galactose, glucose and fucose, whereas the hydrolysate of the cell wall contained meso-diaminopimelic acid, alanine, glutamic acid and glycine in a molar ratio of approximately $0.5: 3: 1: 2$. This combination of cell-wall diamino acid and sugar indicated chemotype IV sensu Lechevalier \& Lechevalier (1970) and variation A1 $\gamma$ of Schleifer \& Kandler (1972). The murein acyl type was determined by using a modification of the colorimetric method of Uchida \& Aida (1977). In contrast to the original procedure, the whole-cell hydrolysate was neutralized by being passed through an ionexchange column (Analytichem Bond Elut SCX; Varian). As expected for a member of the family Nocardiaceae, the sugars of the peptidoglycan were glycolated. Polar lipids were extracted, examined by two-dimensional TLC and identified using published procedures (Minnikin et al., 1977). The polar lipids were composed of diphosphatidylglycerol, phosphatidylethanolamine, phosphatidylinositol, phosphatidylinositol mannoside and some unspecified glycolipids. This pattern matched quite well with those reported by Minnikin et al. (1977) for members of the family Nocardiaceae. To determine the DNA base composition, DNA was extracted and purified by using a Genomic-tip and buffer set (Qiagen). Total DNA was digested with P1 nuclease using a GC kit (Yamasa Shoyu). The DNA G + C content was measured using HPLC (Tamaoka \& Komagata, 1984).

Quinones were extracted with $5 \mathrm{ml}$ chloroform/methanol $(2: 1, \mathrm{v} / \mathrm{v})$ from $10 \mathrm{mg}$ freeze-dried cells that were grown in $300 \mathrm{ml} \mathrm{1/10} \mathrm{trypticase} \mathrm{soy} \mathrm{broth} \mathrm{(TSB).} \mathrm{After} \mathrm{centrifuga-}$ tion, the supernatant was evaporated to dryness and suspended in $10 \mu \mathrm{l}$ acetone. An aliquot of the acetone solution was analysed with an HPLC/PDA/APCI-MS/MS system using a C30 Develosil column (1.0 mm i.d. $\times 150 \mathrm{~mm}$; Nomura Chemical). The crude extract was eluted at a rate of $0.1 \mathrm{ml} \mathrm{min}^{-1}$ with methanol/2-propanol $(8: 2, \mathrm{v} / \mathrm{v})$. Mass spectra were monitored in the mass range $\mathrm{m} / \mathrm{z}$ 200-1200 with the LCQ Advantage system. The capillary temperature was set at $150^{\circ} \mathrm{C}$, the APCI vaporizer temperature was held at $400{ }^{\circ} \mathrm{C}$, the capillary voltage was optimized to $23 \mathrm{~V}$ and the nitrogen gas flow was set to 28 (arbitrary units). HPLC peaks showing the characteristic UV spectra of naphthoquinones (Kroppenstedt, 1985) were identified by comparison with the MS data of authentic menaquinones (MK-7, 8, 9 and 10). Two major menaquinones were detected by using the HPLC/PDA/APCI-MS/MS system. One had the same patterns of UV and MS/MS as those of $\mathrm{MK}-8\left(\mathrm{H}_{4}, \omega\right.$-cycl $)$, which is diagnostic for Nocardia, the other having a UV pattern of MK type with MS/MS data that have not been found previously. Several milligrams of these two quinones were obtained from a $10 \mathrm{l}$ liquid culture, and instrumental analyses using NMR and HRMS indicated the structures to be those of novel cyclic menaquinones, smaragdiquinone $\mathrm{A}-8\left(\mathrm{H}_{4}, \omega\right.$-cycl $)$ and smaragdiquinone $\mathrm{B}-8\left(\mathrm{H}_{4}\right.$, dicycl) (Adachi and others, unpublished data). Smaragdiquinones A and B are abbreviated to SQA and SQB. SQA-8 $\left(\mathrm{H}_{4}, \omega\right.$-cycl $)$ is different from MK- $8\left(\mathrm{H}_{4}, \omega\right.$-cycl) in the structure of the $\omega$-ring (structures are available as Supplementary Fig. S3 in IJSEM Online).

For analysis of the fatty acid and mycolic acid composition, strain Hou_blue ${ }^{\mathrm{T}}$ was grown on TSA for 4 days at $28^{\circ} \mathrm{C}$. For other chemotaxonomic analyses, cells were grown in TSB for 4 days at $28^{\circ} \mathrm{C}$ on a rotary shaker, harvested by centrifugation and washed twice with distilled water and lyophilized. Fatty acid methyl esters were obtained by saponification, methylation and extraction, using the method of Miller (1982) with minor modifications (Kuykendall et al., 1988), from $40 \mathrm{mg}$ cells that had been scraped from Petri dishes. The fatty acid methyl ester mixture was separated by using the Sherlock Microbial Identification System (MIS; Microbial ID) consisting of a 5980 gas chromatograph fitted with a $5 \%$ phenylmethyl silicone capillary column $(0.2 \mathrm{~mm} \times 25 \mathrm{~m})$, a flame-ionization detector, a $7673 \mathrm{~A}$ automatic sampler and a Kayak XA computer (Hewlett Packard). The peaks were integrated automatically and the fatty acids present and their content (\%) were calculated using the MIS software. The gas chromatographic parameters were as follows: carrier gas, ultra-high-purity hydrogen; column head pressure, $60 \mathrm{kPa}$; injection volume, $2 \mu \mathrm{l}$; column split ratio, 100:1; septum purge, $5 \mathrm{ml} \mathrm{min}{ }^{-1}$; column temperature, $170-270{ }^{\circ} \mathrm{C}$ at $5{ }^{\circ} \mathrm{C}$ $\min ^{-1}$; injection port temperature, $250^{\circ} \mathrm{C}$; and detector temperature, $300^{\circ} \mathrm{C}$. The fatty acid pattern of strain Hou_blue $^{\mathrm{T}}$ did not match any of the patterns found previously for members of the genus Nocardia. Interestingly, only very small amounts of 10-methyl-branched fatty acids were present in strain Hou_blue ${ }^{\mathrm{T}}$ (10-methyl-17:0, 0.17\%) and, unlike all other nocardiae, tuberculostearic acid (10methyl-18:0) was not present. In addition, a significant amount of iso-16:0 (8.12\%) was synthesized by strain Hou_blue $^{\mathrm{T}}$; in contrast, this fatty acid, if present at all, has only been found previously in trace amounts among nocardiae and all other members of the suborder Corynebacterineae. Half of the fatty acid methyl ester extract $(0.3 \mathrm{ml})$ was mixed with $0.1 \mathrm{ml} \mathrm{N}$-methyl- $\mathrm{N}$-(trimethylsilyl)-heptafluorobutyramide (MSHFBA) and trimethylchlorosilane (TMCS) [10:1 (v/v); Macherey and Nagel], yielding trimethylsilylated derivatives (TMS-MAME) of the -OH group of mycolic acid methyl ester (MAME) at room temperature (Klatte et al., 1994). A TMS-MAME analysis was carried out using a 5890A gas chromatograph (Hewlett Packard) equipped with a flame-ionization detector and a 7673A automatic sampler (Hewlett Packard). Chromatographic data were sampled and processed by using a Vectra Series 4 computer (Hewlett Packard) with MIS version 3.3 software package (Microbial ID). The TMS-MAME analysis was performed using a $12 \mathrm{~m}$ HT5 column (SGE) of $0.32 \mathrm{~mm}$ i.d. and $0.1 \mu \mathrm{m}$ film 
thickness using $\mathrm{H}_{2}$ as the carrier gas and a split ratio of $50: 1$. The oven temperature was increased from 210 to $400{ }^{\circ} \mathrm{C}$, at $10{ }^{\circ} \mathrm{C} \mathrm{min}^{-1}$, the final temperature being held for $10 \mathrm{~min}$. The MIS apparatus was calibrated with a series of saturated TMS-MAMEs derived from Corynebacterium bovis DSM $20582^{\mathrm{T}}$, Rhodococcus erythropolis DSM $43066^{\mathrm{T}}$, Rhodococcus rhodnii DSM $43336^{\mathrm{T}}$ and Gordonia sputi DSM 44019. The chain length of the mycolic acids of strain Hou_blue ${ }^{\mathrm{T}}$ was shorter $\left(\mathrm{C}_{43}-\mathrm{C}_{49}\right)$ than that found in other nocardiae $\left(\mathrm{C}_{50}-\right.$ $\mathrm{C}_{62}$ ), the pattern being very complex, i.e. highly unsaturated mycolic acids. It was therefore difficult to identify the numbers of the double bond. A detailed comparison of the chemotaxonomic data of strain Hou_blue $\mathrm{T}^{\mathrm{T}}$ with those of other mycolic acid-containing genera is given in Table 1. Results of phenotypic characterization by using Biolog and API ZYM assays are given in the species description.

The results of $16 \mathrm{~S}$ rRNA and gyrB gene sequence analyses, the cell wall and peptidoglycan characterization and the polar lipid analysis indicated that strain Hou_blue $\mathrm{H}^{\mathrm{T}}$ belonged to the family Nocardiaceae. The profiles of quinones, fatty acids and mycolic acids indicated that strain Hou_blue ${ }^{\mathrm{T}}$ should be classified as representing a novel genus and species of the family Nocardiaceae, for which the name Smaragdicoccus niigatensis gen. nov., sp. nov. is proposed.

\section{Description of Smaragdicoccus gen. nov.}

Smaragdicoccus [Sma.rag.di.coc'cus. L. n. smaragdus malachite; N.L. masc. n. coccus (from Gr. masc. n. kokkos), grain; N.L. masc. n. Smaragdicoccus malachite(-coloured) coccus].

Gram-positive, non-spore-forming cocci. The type of cellwall diamino acid and sugar is chemotype IV and variation A $1 \gamma$. Sugars of the peptidoglycan are glycolated. Polar lipids are composed of diphosphatidylglycerol, phosphatidylethanolamine, phosphatidylinositol, phosphatidylinositol mannoside and some unspecified glycolipids. Carbonchain length of mycolic acid is $\mathrm{C}_{43}-\mathrm{C}_{49}$. Major fatty acids are straight-chain saturated and unsaturated fatty acids, whereas 10-methyl-branched fatty acids are present in trace amounts or absent. Two menaquinone species, SQA-8 $\left(\mathrm{H}_{4}\right.$, $\omega$-cycl $)$ and SQB-8 $\left(\mathrm{H}_{4}\right.$, dicycl $)$, are present. $16 \mathrm{~S}$ rRNA and gyrB gene sequence analyses indicate that the genus is a member of the family Nocardiaceae. The type species is Smaragdicoccus niigatensis.

\section{Description of Smaragdicoccus niigatensis sp. nov.}

Smaragdicoccus niigatensis (ni.i.ga.ten'sis. N.L. masc. adj. niigatensis, pertaining to the Niigata Prefecture of Japan, the source of the soil from which the organism was isolated).

Table 1. Chemotaxonomic markers of Smaragdicoccus gen. nov. and other genera of the suborder Corynebacterineae

Taxa: 1, strain Hou_blue ${ }^{\mathrm{T}}$; 2, Nocardia; 3, Skermania; 4, Rhodococcus; 5, Gordonia; 6, Williamsia; 7, Mycobacterium; 8, Tsukamurella; 9, Segniliparus; 10, Turicella; 11, Dietzia; 12, Corynebacterium; 13, Corynebacterium amycolatum. Chemotaxonomic characteristics summarized by Kämpfer et al. (1999) were updated. The whole-cell lysate of all organisms contained meso-diaminopimelic acid. +, Present; -, absent; $\mathrm{ND}$, not determined.

\begin{tabular}{|c|c|c|c|c|c|c|c|c|c|c|c|c|c|}
\hline Characteristic & 1 & 2 & 3 & 4 & 5 & 6 & 7 & 8 & $9^{*}$ & 10 & 11 & 12 & 13 \\
\hline Acyl type $\dagger$ & G & G & G & G & G & G & G & G & $\mathrm{ND}$ & $\mathrm{ND}$ & A & A & $\mathrm{ND}$ \\
\hline $\begin{array}{l}\text { Major } \\
\text { menaquinone }\end{array}$ & $\begin{array}{l}\text { SQA- } 8\left(\mathrm{H}_{4},\right. \\
\omega-\mathrm{cycl}) \\
\text { SQB- } 8\left(\mathrm{H}_{4},\right. \\
\text { dicycl })\end{array}$ & $\begin{array}{l}\text { MK-8 } \\
\left(\mathrm{H}_{4},\right. \\
\omega \text {-cycl })\end{array}$ & $\begin{array}{l}\text { MK-8 } \\
\left(\mathrm{H}_{4},\right. \\
\omega \text {-cycl })\end{array}$ & $\begin{array}{c}\text { MK-8 } \\
\left(\mathrm{H}_{2}\right)\end{array}$ & $\begin{array}{l}\text { MK-9 } \\
\left(\mathrm{H}_{2}\right)\end{array}$ & $\begin{array}{c}\text { MK-9 } \\
\left(\mathrm{H}_{2}\right)\end{array}$ & $\begin{array}{c}\text { MK-9 } \\
\left(\mathrm{H}_{2}\right)\end{array}$ & MK-9 & ND & $\begin{array}{l}\text { MK-10, } \\
\text { MK-11 }\end{array}$ & $\begin{array}{c}\mathrm{MK}-8 \\
\left(\mathrm{H}_{2}\right)\end{array}$ & $\begin{array}{l}\mathrm{MK}-8 \\
\left(\mathrm{H}_{2}\right)\end{array}$ & MK-9 \\
\hline PE $\ddagger$ & + & + & + & + & + & + & + & + & ND & ND & - & $-\S$ & ND \\
\hline $\begin{array}{l}\text { Fatty acid } \\
\text { compositionll }\end{array}$ & $S, U$ & $\mathrm{~S}, \mathrm{U}, \mathrm{T}$ & $\mathrm{S}, \mathrm{U}, \mathrm{T}$ & $\mathrm{S}, \mathrm{U}, \mathrm{T}$ & $\mathrm{S}, \mathrm{U}, \mathrm{T}$ & S, U, T & $\mathrm{S}, \mathrm{U}, \mathrm{T}$ & $\mathrm{S}, \mathrm{U}, \mathrm{T}$ & $\mathrm{S}, \mathrm{U}, \mathrm{T}$ & $\mathrm{S}, \mathrm{U}, \mathrm{T}$ & $\mathrm{S}, \mathrm{U}, \mathrm{T}$ & S, US & $S, U$ \\
\hline $\begin{array}{l}\text { Mycolate size } \\
\text { (no. of carbons)\# }\end{array}$ & $43-49$ & $50-62$ & $58-64$ & $34-54$ & $54-66$ & $50-56$ & 70-90 & $64-78$ & ND & - & $34-38$ & $22-36$ & - \\
\hline $\begin{array}{l}\text { DNA G }+ \text { C } \\
\text { content }(\mathrm{mol} \%)\end{array}$ & 63.7 & $64-72$ & 68 & $63-73$ & $63-69$ & $64-65$ & $70-72$ & $67-68$ & $68-72$ & $65-72$ & 73 & $51-67$ & ND \\
\hline
\end{tabular}

${ }^{\star}$ Data from Butler et al. (2005).

$\dagger$, Acetylated muramic acid; G, glycolated muramic acid.

$¥$ Phosphatidylethanolamine.

§resent in C. bovis and Corynebacterium urealyticum (Kämpfer et al., 1999).

IIS, Saturated fatty acid; T, tuberculostearic acid; U, unsaturated fatty acid.

STuberculostearic acid present in Corynebacterium ammnoniagenes, C. bovis, Corynebacterium minutissimum, C. urealyticum and Corynebacterium variabile (Kämpfer et al., 1999).

\#Number of carbon atoms in the mycolic acid molecule, range of homologous series of mycolic acids. 
Cells are coccoid without branching $(0.86 \times 0.86 \mu \mathrm{m})$. Utilizes the following carbon sources after incubation for 14 days at $30^{\circ} \mathrm{C}$ : D-fructose, D-glucose, sodium n-butyrate and hexadecane. After prolonged incubation (1 month) growth occurs with sucrose. Better growth is observed on $\mathrm{W}$-medium containing 0.1 than $1 \%$ of these carbon sources. The following carbon sources are not used for growth: L-arabinose, myo-inositol, D-mannitol, L-rhamnose, raffinose and D-xylose. Positive for activities of esterase (C4), esterase lipase (C8), lipase (C4), leucine arylamidase and naphthol-AS-BI-phosphohydrolase (API ZYM).

The DNA G + C content of the type strain is $63.7 \mathrm{~mol} \%$. The type strain is Hou_blue ${ }^{\mathrm{T}}\left(=\right.$ MBIC $\left.06267^{\mathrm{T}}=\mathrm{DSM} 44881^{\mathrm{T}}\right)$, which was isolated from soil samples from an oil spring in Niigata, Japan.

\section{Acknowledgements}

We thank Dr Jean Euzéby for his help with the name of the novel species. We also acknowledge Ayako Matsuzaki, Tomomi Haga, and Yukiko Itazawa for their technical assistance. This work was supported by the New Energy and Industrial Technology Development Organization (NEDO).

\section{References}

Becker, B., Lechevalier, M. P., Gordon, R. E. \& Lechevalier, H. A. (1964). Rapid differentiation between Nocardia and Streptomyces by paper chromatography of whole-cell hydrolysates. Appl Microbiol 12, 421-423.

Butler, W. R., Floyd, M. M., Brown, J. M., Toney, S. R., Daneshvar, M. I., Cooksey, R. C., Carr, J., Steigerwalt, A. G. \& Charles, N. (2005), Novel mycolic acid-containing bacteria in the family Segniliparaceae fam. nov., including the genus Segniliparus gen. nov., with descriptions of Segniliparus rotundus sp. nov. and Segniliparus rugosus sp. nov. Int J Syst Evol Microbiol 55, 1615-1624.

Cole, J. R., Chai, B., Farris, R. J., Wang, Q., Kulam, S. A., McGarrell, D. M., Garrity, G. M. \& Tiedje, J. M. (2005). The Ribosomal Database Project (RDP-II): sequences and tools for high-throughput rRNA analysis. Nucleic Acids Res 33, D294-D296.

Gerhardt, P., Murray, R. G. E., Wood, W. A. \& Krieg, N. R. (editors) (1994). Methods for General and Molecular Bacteriology. Washington, DC: American Society for Microbiology.

Guindon, S. \& Gascuel, O. (2003). A simple, fast, and accurate algorithm to estimate large phylogenies by maximum likelihood. Syst Biol 52, 696-704.

Harper, J. J. \& Davis, G. H. G. (1979). Two-dimensional thin-layer chromatography for amino acid analysis of bacterial cell walls. Int J Syst Bacteriol 29, 56-58.
Kämpfer, P., Andersson, M. A., Rainey, F. A., Kroppenstedt, R. M. \& Salkinoja-Salonen, M. (1999). Williamsia muralis gen. nov., sp. nov., isolated from the indoor environment of a children's day care centre. Int J Syst Bacteriol 49, 681-687.

Katsuta, A., Adachi, K., Matsuda, S., Shizuri, Y. \& Kasai, H. (2005). Ferrimonas marina sp. nov. Int J Syst Evol Microbiol 55, 1851-1855.

Klatte, S., Kroppenstedt, R. M. \& Rainey, F. A. (1994). Rhodococcus opacus sp. nov., an unusual nutritionally versatile Rhodococcusspecies. Syst Appl Microbiol 17, 355-360.

Kroppenstedt, R. M. (1985). Fatty acid and menaquinone analysis of actinomycetes and related organisms. In Chemical Methods in Bacterial Systematics, pp. 173-199. Edited by M. Goodfellow \& D. E. Minnikin. No. 20 SAB Technical Series. London: Academic Press.

Kumar, S., Tamura, K. \& Nei, M. (2004). MEGA3: integrated software for Molecular Evolutionary Genetics Analysis and sequence alignment. Brief Bioinform 5, 150-163.

Kuykendall, L. D., Roy, M. A., O’Neill, J. J. \& Devine, T. E. (1988). Fatty acids, antibiotic resistance, and deoxyribonucleic acid homology groups of Bradorhizobium japonicum. Int J Syst Bacteriol 38, 358-361.

Lechevalier, H. A. \& Lechevalier, M. P. (1970). A critical evaluation of the genera of aerobic actinomycetes. In The Actinomycetales, pp. 393-405. Edited by H. Prauser. Jena: VEB Gustav Fisher Verlag.

Miller, L. T. (1982). Single derivatization method for routine analysis of bacterial whole-cell fatty acid methyl esters, including hydroxy acids. J Clin Microbiol 16, 584-586.

Minnikin, D. E., Patel, P. V., Alshamaony, L. \& Goodfellow, M. (1977). Polar lipid composition in the classification of Nocardia and related bacteria. Int J Syst Bacteriol 27, 104-117.

Peng, X., Misawa, N. \& Harayama, S. (2003). Isolation and characterization of thermophilic bacilli degrading cinnamic, 4coumaric, and ferulic acids. Appl Environ Microbiol 69, 1417-1427.

Schleifer, K. H. \& Kandler, O. (1972). Peptidoglycan types of bacterial cell walls and their taxonomic implications. Bacteriol Rev 36, 407-477.

Stackebrandt, E., Rainey, F. A. \& Ward-Rainey, N. L. (1997). Proposal for a new hierarchic classification system, Actinobacteria classis nov. Int J Syst Bacteriol 47, 479-491.

Tamaoka, J. \& Komagata, K. (1984). Determination of DNA base composition by reversed-phase high-performance liquid chromatography. FEMS Microbiol Lett 25, 125-128.

Thompson, J. D., Gibson, T. J., Plewniak, F., Jeanmougin, F. \& Higgins, D. G. (1997). The CLUSTAL_X windows interface: flexible strategies for multiple sequence alignment aided by quality analysis tools. Nucleic Acids Res 25, 4876-4882.

Uchida, K. \& Aida, K. (1977). Acyl type of bacterial cell wall: its simple identification by a colorimetric method. J Gen Appl Microbiol 23, 249-260.

Wako Pure Chemical Industries (1989). Technical note on the system of PTC-amino acid analysis. Osaka: Wako Pure Chemical Industries (in Japanese). 